\title{
Characterization of Dried Whey Protein Concentrate and Isolate Flavor
}

\author{
M. E. Carunchia Whetstine, A. E. Croissant, and M. A. Drake \\ Department of Food Science, Southeast Dairy Foods Research Center, \\ North Carolina State University, Raleigh 27695
}

\begin{abstract}
The flavor of whey protein concentrates (WPC 80) and whey protein isolates (WPI) was studied using instrumental and sensory techniques. Four WPC 80 and $4 \mathrm{WPI}$, less than 3 mo old, were collected in duplicate from 6 manufacturers in the United States. Samples were rehydrated and evaluated in duplicate by descriptive sensory analysis. Duplicate samples with internal standards were extracted with diethyl ether. Extracts were then distilled to remove nonvolatile material using high vacuum distillation. Volatile extracts were analyzed using gas chromatography/olfactometry with post peak intensity analysis and aroma extract dilution analysis. Compounds were identified by comparison of retention indices, odor properties, and gas chromatography/mass spectrometry against reference standards. Whey proteins exhibited sweet aromatic, cardboard/wet paper, animal/wet dog, soapy, brothy, cucumber, and cooked/milky flavors, along with the basic taste bitter, and the feeling factor astringency. Key volatile flavor compounds in WPC 80 and WPI were butanoic acid (cheesy), 2-acetyl-1-pyrroline (popcorn), 2-methyl-3-furanthiol (brothy/burnt), 2,5-dimethyl-4-hydroxy-3(2H)-furanone (maple/spicy), 2-nonenal (fatty/old books), (E,Z)-2,6-nonadienal (cucumber), and (E,Z)-2,4decadienal (fatty/oxidized). This baseline data on flavor and flavor sources in whey proteins will aid ongoing and future research and will help to identify the most appropriate whey ingredients to use to control or minimize flavor variability in whey enhanced products.
\end{abstract}

(Key words: whey protein concentrate, whey protein isolate, flavor)

Abbreviation key: AEDA = aroma extract dilution analysis, $\log _{3} \mathbf{F D}=\log _{3}$ flavor dilution, $\mathbf{G C} / \mathbf{O}=$ gas chromatography/olfactometry, $\mathbf{R I}=$ retention index, $\mathbf{W P C}=$ whey protein concentrates, $\mathbf{W P I}=$ whey protein isolates.

Received March 5, 2005.

Accepted July 28, 2005.

Corresponding author: M. A. Drake; e-mail: mdrake@ncsu.edu.

\section{INTRODUCTION}

Dried whey and dried whey products are important ingredients in the food industry. Although liquid whey is not often used as a food ingredient, production exceeded 39 million $\mathrm{kg}$ ( 86 million pounds) in 2004 (USDA, 2005). Liquid whey is further processed into dried whey powder, whey protein concentrates (WPC; 35 to $80 \%$ protein), and whey protein isolates (WPI; $>90 \%$ protein). Dried whey proteins are commonly used as ingredients due to their exceptional functional characteristics including gelation and viscosity (Morr and Foegeding, 1990). Whey proteins also provide an excellent way to fortify foods with proteins and thus increase their overall nutritional value (Quach et al., 1999).

The flavor of whey is one of the limiting factors in its widespread usage. It has been suggested that off-flavors such as brothy, diacetyl, sourness, and bitterness are the main sensory attributes that limit whey protein usage in bland products (McGugan et al., 1979; Quach et al., 1999). As whey is processed into WPC 80 and WPI, there are many potential sources of flavor formation. Because liquid whey is pooled (sometimes from different types of cheese) before processing into WPC 80 and WPI, there are many sources of flavor variability. Swaisgood (1996) stated that volatile lipid oxidation products were the main sources of off-flavors in both liquid and dried whey, although whey contains only a small amount of lipid. Other studies have confirmed a wide variety of volatile lipid oxidation products in liquid whey and dried whey products, including methyl ketones, aldehydes, and free fatty acids (Hidalgo and Kinsella, 1989; Mills, 1993; Carunchia Whetstine et al., 2003a; Karagul-Yuceer et al., 2003a; Mahajan et al., 2004). Proteolysis is also an important flavor reaction in whey. Proteolytic enzymes, including chymosin, carry over into the whey and may promote the degradation of amino acids, leading to undesirable flavor formation (Holmes et al., 1977; Amundson, 1984). Variability in the type and concentration of free amino acids in whey has also been reported (Mavropoulou and Kosikowski, 1972; Mills, 1993) and may be a source of flavor variability in dried whey products. Proteins may also bind volatile flavor compounds during processing (Stevenson and 
Chen, 1996), thereby contributing to flavor formation in the end product.

Previous studies (Carunchia Whetstine et al., 2003a; Karagul-Yuceer et al., 2003a) showed that metallic and cardboard flavors are present in liquid Cheddar whey. Furthermore, considerable variability in flavor and flavor volatiles existed in liquid Cheddar whey from different starter culture rotations and from different production facilities. Dried whey ingredients have been associated with oxidized, unpleasant flavors that are not pleasing to consumers (Morr and Ha, 1991; Branger et al., 1999). Few studies have specifically addressed the flavor of dried whey or whey proteins (Stevenson and Chen, 1996; Quach et al., 1999; Mahajan et al., 2004). Mahajan et al. (2004) characterized the aromaactive components from 2 samples of sweet whey powder. Sensory properties were not addressed. Other studies have optimized total volatile component analysis (not aroma-active components) (Quach et al., 1999) or evaluated processing methods to minimize volatile component entrapment (Stevenson and Chen, 1996). To our knowledge, the application of quantitative sensory analysis in conjunction with instrumental flavor volatile analysis on multiple whey protein samples has not been conducted. The objectives of this research were to identify and characterize sensory flavor and volatile aroma-active compounds that contribute to flavor in WPC 80 and WPI. Products from different domestic manufacturers as well as different cheese types were evaluated. A previously established defined sensory language for dried dairy ingredients (Drake et al., 2003) was applied by a trained sensory panel in conjunction with instrumental volatile analysis to characterize flavor and flavor variability in this important food ingredient.

\section{MATERIALS AND METHODS}

\section{Whey Proteins}

Whey protein concentrates $(\mathrm{n}=7)$ and WPI $(\mathrm{n}=8)$ (15 kg, commercially packaged) from different cheese types (Table 1) were received from different US manufacturers within $48 \mathrm{~h}$ of production. Duplicate samples were received from each manufacturer in the fall of 2004. Subsamples $(500 \mathrm{~g})$ were taken and stored in glass jars flushed with nitrogen, immediately frozen at $-80^{\circ} \mathrm{C}$, and analyzed within 3 mo of receipt. Whey protein concentrate and WPI samples were reconstituted to $10 \%$ solids using deodorized water (prepared by boiling $4 \mathrm{~L}$ of distilled water until its volume was decreased by one-third) and blended with a hand-held electric mixer for sensory and instrumental analyses.

Analyses of $\mathrm{pH}$, moisture, fat, protein, and mineral were conducted on all whey proteins in duplicate using
Table 1. Whey protein concentrate 80 (WPC) and whey protein isolates (WPI) used in the study. ${ }^{1}$

\begin{tabular}{clll}
\hline Sample & Manufacturer & Cheese type & $\begin{array}{l}\text { Region } \\
\text { of US }\end{array}$ \\
\hline WPC 80 & & Primarily Mozzarella & Midwest \\
WPC 1 & 1 & Primarily Mozzarella & Midwest \\
WPC 2 & 1 & Mozzarella & Midwest \\
WPC 3 & 2 & Mozzarella & Midwest \\
WPC 4 & 2 & Mozzarella & West coast \\
WPC 5 & 3 & Cheddar & West coast \\
WPC 6 & 4 & Cheddar & West coast \\
WPC 7 & 4 & Primarily Cheddar & Midwest \\
WPI & & Primarily Cheddar & Midwest \\
WPI 1 & 1 & Cheddar & Midwest \\
WPI 2 & 1 & Cheddar & Midwest \\
WPI 3 & 5 & Cheddar & West coast \\
WPI 4 & 5 & Cheddar & West coast \\
WPI 5 & 4 & Cheddar & West coast \\
WPI 6 & 4 & Cheddar & West coast \\
WPI 7 & 6 & &
\end{tabular}

${ }^{1}$ All products were $<3$ mo old before analysis.

${ }^{2}$ Geographical region of United States in which the product was manufactured.

standard methods. The $\mathrm{pH}$ values were determined by rehydrating the powders and measuring the $\mathrm{pH}$ using a $\mathrm{pH}$ electrode. Fat content was determined by Mojonnier analysis (Mojonnier Bros. Co., Chicago, IL; Wehr and Frank, 2004). Moisture was determined by the vacuum oven method, and ash content was determined using a muffle furnace. Protein concentration was determined by the Kjeldahl method using a conversion factor of 6.38 to convert total $\mathrm{N}$ to protein concentration (Wehr and Frank, 2004). Mineral analysis (calcium, magnesium, potassium, sodium, and phosphate) was conducted using inductively coupled plasma atomic emission spectroscopy.

\section{Descriptive Sensory Analysis}

A trained sensory panel $(n=7)$ evaluated the flavor attributes of the reconstituted whey proteins using a previously published lexicon for dried dairy ingredients (Drake et al., 2003). The definitions and references for the terms used are given in Table 2. Panelists each received $100 \mathrm{~h}$ of training on aroma and flavor evaluation of dried dairy ingredients, including both WPI and WPC 80. Flavor and taste intensities were scaled using the 15-point universal intensity scale characterized by the Spectrum descriptive analysis method (Meilgaard et al., 1999; Drake and Civille, 2003). Consistent with Spectrum descriptive analysis training, panelists were presented with reference solutions of sweet, sour, salty, and bitter tastes to learn to consistently use the universal intensity scale (Meilgaard et al., 1999; Drake and Civille, 2003). Following consistent use of the Spectrum 
Table 2. References for descriptive sensory analysis of whey proteins. ${ }^{1}$

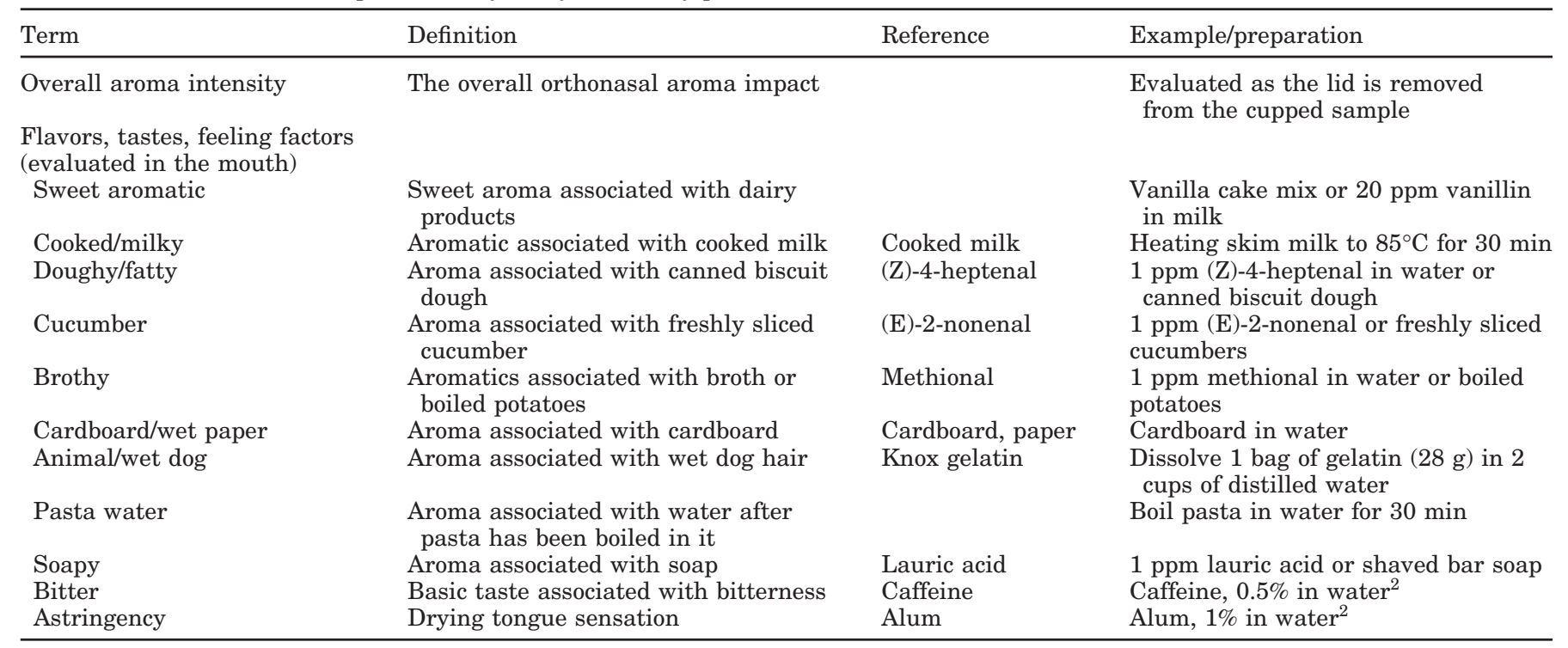

${ }^{1}$ Adapted from Drake et al., 2003; Karagul-Yuceer et al., 2003a.

${ }^{2}$ Meilgaard et al., 1999.

scale with basic tastes, panelists learned to identify and scale flavor descriptors using the same intensity scale through presentation and discussion of flavor definitions, references (Table 2), and a wide array of rehydrated dried dairy ingredients. Samples were reconstituted $24 \mathrm{~h}$ before evaluation at $10 \%$ solids using deodorized water and stored at $5^{\circ} \mathrm{C}$. Samples were tempered to $12^{\circ} \mathrm{C}$ and evaluated in duplicate by each panelist in a randomized balanced block design on separate occasions in $125-\mathrm{mL}$ lidded plastic cups identified with 3 digit random codes.

\section{Chemicals}

Diethyl ether (anhydrous, 99.8\%), sodium chloride (99\%), sodium sulfate (99\%), and 2-methyl-3-heptanone (internal standard for neutral/basic fraction) were obtained from Aldrich Chemical Company (St. Louis, MO). Compounds in Tables 7 and 8 were provided by Aldrich (St. Louis, MO) with the following exceptions: 1-octen-3-one was obtained from Lancaster (Windham, $\mathrm{NH}$, 4-methoxyphenol was obtained from TCI America (Portland, OR) and 2-acetyl-1-pyrroline was not commercially available. Sodium bicarbonate $(99.7 \%)$ and hydrochloric acid $(36.5 \%)$ were obtained from Fisher Scientific (Pittsburgh, PA).

\section{Volatile Extract Preparation}

Direct solvent extraction. Whey protein concentrate and WPI volatile extracts were prepared using the methods of Milo and Reineccius (1997). Whey proteins $(20 \mathrm{~g})$ were reconstituted to $10 \%$ solids in duplicate and divided into 4 Teflon bottles (capacity of $250 \mathrm{~mL}$ ) with Tefzel closures per duplicate. Two hundred milliliters of diethyl ether $(50 \mathrm{~mL} / \mathrm{bottle})$ with $10 \mu \mathrm{L}$ of internal standard $(10 \mu \mathrm{L}$ of 2-methyl-3-heptanone and 50 $\mu \mathrm{L}$ of 2-methyl pentanoic acid in $5 \mathrm{~mL}$ of methanol) and $60 \mathrm{~g}$ of $\mathrm{NaCl}$ were combined and equally distributed among each bottle. The mixtures were shaken for 30 min on a Roto mix (Type 50800; Thermolyne, Dubuque, IA) at high speed. The bottles were then centrifuged at $735 \times g$ for $15 \mathrm{~min}$ to separate the nonpolar solvent phase from the mixture. This solvent phase was subsequently removed via pipette and saved in a glass jar. The procedure was repeated twice with the addition of $50 \mathrm{~mL}$ of diethyl ether to each bottle. The third addition was centrifuged at $325 \times g$. The solvent phases were combined and dried over anhydrous sulfate and concentrated to $120 \mathrm{~mL}$ using a Vigreux column (Fisher Scientific, Allentown, PA).

High-vacuum distillation. Volatile compounds from WPC 80 and WPI extracts were separated using a high vacuum distillation technique detailed by Karagul-Yuceer et al. (2001). The distillation process began by placing the extract into a 1-L round-bottomed flask and immersing it into a Dewar vessel containing liquid nitrogen until shell frozen. The frozen flask was then immediately connected to a distillation unit equipped with a rough pump/diffusion pump as the vacuum source (about $10^{-4}$ Torr), a receiving tube, and a waste tube. The receiving tube and waste tube were held in 
separate Dewar vessels containing liquid nitrogen until distillation was completed $(4 \mathrm{~h})$. For the first $2 \mathrm{~h}$, the sample flask was held at room temperature. During the second $2 \mathrm{~h}$, the sample was kept at constant temperature in a water bath $\left(50^{\circ} \mathrm{C}\right)$. After distillation, the distillate was concentrated to $20 \mathrm{~mL}$ under a stream of nitrogen gas. The concentrated distillate was then washed twice with $3 \mathrm{~mL}$ of sodium bicarbonate $(0.5 M)$ and vigorously shaken. It was then washed 3 times with 2 $\mathrm{mL}$ of saturated sodium chloride solution. The upper layer (ether) containing the neutral/basic fraction was collected in a glass tube using a pipette. The distilled extracts were then dried over anhydrous sodium sulfate and concentrated to $0.5 \mathrm{~mL}$ under a stream of nitrogen gas. Acidic volatiles were recovered by acidifying the bottom layer (aqueous phase) with about $5 \mathrm{~mL}$ of 6.2 $M$ hydrochloric acid to $\mathrm{pH} 2$ to 2.5 and extracting the sample 3 times with $5 \mathrm{~mL}$ of diethyl ether. The extracted acidic volatiles were then dried over anhydrous sodium sulfate before concentration to $0.5 \mathrm{~mL}$ under nitrogen.

\section{Gas Chromatography/Olfactometry}

Two methods of sniffing were used for the evaluation of aroma-active volatile compounds in the extracts. Post peak intensity was conducted on all fractions of all samples. Representative samples were then analyzed using aroma extract dilution analysis (AEDA; Grosch, 1993; Van Ruth, 2001).

Post peak intensity. An HP5890 series II gas chromatograph (Hewlett-Packard Co., Palo Alto, CA) equipped with a flame-ionization detector, a sniffing port, and a splitless injector was used for gas chromatography/olfactometry (GC/O). Both the neutral/basic and acidic fractions were analyzed from each duplicate extraction. Two microliters was injected onto a polar capillary column (DB-WAX, $30 \mathrm{~m}$ length $\times 0.25 \mathrm{~mm}$ i.d. $\times 0.25 \mu \mathrm{m}$ film thickness; J\&W Scientific, Folsom, CA) and a nonpolar column (DB-5MS, 30 m length $\times 0.25$ $\mathrm{mm}$ i.d. $\times 0.25 \mu \mathrm{m}$ film thickness; J\&W Scientific). Column effluent was split 1:1 between the flame-ionization detector and sniffing port using deactivated fused silica capillaries $(1 \mathrm{~m}$ length $\times 0.25 \mathrm{~mm}$ i.d. $)$. The oven temperature was programmed from 40 to $200^{\circ} \mathrm{C}$ at a rate of $10^{\circ} \mathrm{C} / \mathrm{min}$ with an initial hold for $3 \mathrm{~min}$ and a final hold of $20 \mathrm{~min}$. The flame-ionization detector and sniffing port were maintained at a temperature of $250^{\circ} \mathrm{C}$. The sniffing port was supplied with humidified air at 30 $\mathrm{mL} / \mathrm{min}$. Post peak intensity was used to characterize the odorants in the extracts (Van Ruth, 2001). Two experienced panelists (each with more than $150 \mathrm{~h}$ of experience) sniffed the neutral/basic and acidic fractions of the WPC80 and WPI extracts twice on the 2 columns. Sniffers described the odor and scored the intensity of odorants in the extracts using a 10-point numerical intensity scale (Van Ruth, 2001).

AEDA. The same conditions and system were used for AEDA analysis as in post peak intensity. Representative samples were selected for AEDA based on aromaactive volatile differences identified during post peak intensity and by flavor differences identified by descriptive sensory analysis. Four representative WPC 80 (samples 2, 3, 5, and 6) and 3 representative WPI (samples 2,4 , and 7 ) were analyzed (Table 1). Each neutral/ basic extract was injected onto a DB-5MS capillary column $\left(30 \mathrm{~m}\right.$ length $\times 0.25 \mathrm{~mm}$ i.d. $\times 0.25 \mu \mathrm{m} \mathrm{d}_{\mathrm{f}}$; J\&W Scientific, Folsom, CA) and each acidic fraction was injected on to a DB-WAX capillary column (30 m length $\times 0.25 \mathrm{~mm}$ i.d. $\times 0.25 \mu \mathrm{m}$ film thickness; J\&W Scientific) under the above conditions. The extracts were diluted stepwise with diethyl ether at a ratio of $1 / 3(\mathrm{vol} / \mathrm{vol})$. Two experienced sniffers with more than $150 \mathrm{~h}$ training on GC/O evaluated each dilution. The dilution procedure was repeated until sniffers detected no odorants. The highest dilution was reported as the flavor dilution $\left(\log \mathbf{F D}_{3}\right)$ factor (Grosch, 1993).

\section{Gas Chromatography/Mass Spectrometry}

Gas chromatography/mass spectrometry analysis of the extracts used a HP5890 Series II GC/HP 5972 mass selective detector (Hewlett-Packard). Separations were performed on a fused silica capillary column (DB-5MS, $30 \mathrm{~m}$ length $\times 0.25 \mathrm{~mm}$ i.d. $\times 0.25 \mu \mathrm{m}$ film thickness, J\&W Scientific). Helium gas was used as a carrier at a constant flow of $1 \mathrm{~mL} / \mathrm{min}$. Oven temperature was programmed from 40 to $200^{\circ} \mathrm{C}$ at a rate of $5^{\circ} \mathrm{C} / \mathrm{min}$ with initial and final hold times of 5 and $45 \mathrm{~min}$, respectively. Mass selective detector conditions were as follows: capillary direct interface temperature, $280^{\circ} \mathrm{C}$; ionization energy, $70 \mathrm{eV}$; mass range, 33 to $330 \mathrm{amu}$; scan rate, 5 scans/s. Each extract $(2 \mu \mathrm{L})$ was injected in the splitless mode. Duplicate analyses were performed on each sample.

Identification of odorants. For positive identifications, retention indices (RI), mass spectra, and odor properties of unknowns were compared with those of authentic standard compounds analyzed under identical conditions. Tentative identifications were based on comparing mass spectra of unknown compounds with authentic standards or on matching the RI values and odor properties of unknowns against those of authentic standards. For the calculation of retention indices, an nalkane series was used (Van den Dool and Kratz, 1963).

Quantification of odorants. Selected compounds were quantified. The area ratio (area of internal standard/area of compound) was multiplied by the concen- 
Table 3. Proximate analysis of whey protein concentrate (WPC 80) from different manufacturers. ${ }^{1}$

\begin{tabular}{|c|c|c|c|c|c|c|c|}
\hline \multirow[b]{2}{*}{ Attribute } & \multicolumn{2}{|c|}{ Manufacturer 1} & \multicolumn{2}{|c|}{ Manufacturer 2} & \multirow{2}{*}{$\frac{\text { Manufacturer } 3}{\text { WPC } 5}$} & \multicolumn{2}{|c|}{ Manufacturer 4} \\
\hline & WPC 1 & WPC 2 & WPC 3 & WPC 4 & & WPC 6 & WPC 7 \\
\hline $\mathrm{pH}$ & $6.73^{\mathrm{a}}$ & $5.83^{\mathrm{c}}$ & $6.25^{\mathrm{b}}$ & $6.23^{\mathrm{b}}$ & $5.89^{\mathrm{c}}$ & $6.23^{\mathrm{b}}$ & $6.60^{\mathrm{a}}$ \\
\hline Moisture (\%) & $4.09^{\mathrm{b}}$ & $3.77^{\mathrm{d}}$ & $3.97^{\mathrm{c}}$ & $3.25^{\mathrm{f}}$ & $3.52^{\mathrm{e}}$ & $4.51^{\mathrm{a}}$ & $4.02^{\mathrm{bc}}$ \\
\hline Protein (\% dry weight basis) & $76.52^{\mathrm{cd}}$ & $76.75^{\text {cd }}$ & $74.78^{\mathrm{e}}$ & $76.06^{\mathrm{d}}$ & $77.44^{\text {bc }}$ & $78.2^{\mathrm{b}}$ & $80.00^{\mathrm{a}}$ \\
\hline Fat (\% dry weight basis) & $6.29^{\mathrm{a}}$ & $6.27^{\mathrm{a}}$ & $4.53^{\mathrm{d}}$ & $4.87^{\mathrm{c}}$ & $5.39^{\mathrm{b}}$ & $5.41^{b}$ & $5.55^{\mathrm{b}}$ \\
\hline Calcium $(\mathrm{mg} / 100 \mathrm{~g})$ & $846.5^{\mathrm{a}}$ & $829.0^{\mathrm{a}}$ & $509.5^{\mathrm{cd}}$ & $489.0^{\mathrm{d}}$ & $378.5^{\mathrm{e}}$ & $529.5^{\mathrm{bc}}$ & $548.0^{\mathrm{b}}$ \\
\hline Sodium (mg/100 g) & $150.0^{\mathrm{bc}}$ & $144.5^{\mathrm{cd}}$ & $151.0^{\mathrm{bc}}$ & $138.0^{\mathrm{d}}$ & $164.5^{\mathrm{a}}$ & $157.0^{\mathrm{ab}}$ & $151.0^{\mathrm{bc}}$ \\
\hline Phosphate (mg/100 g) & $364.5^{\mathrm{a}}$ & $356.5^{\mathrm{ab}}$ & $349.5^{\mathrm{bc}}$ & $343.0^{\mathrm{ab}}$ & $318.0^{\mathrm{e}}$ & $339.5^{\mathrm{cd}}$ & $330.5^{\mathrm{de}}$ \\
\hline
\end{tabular}

${ }^{\mathrm{a}-\mathrm{f}}$ Means in a row followed by different letters are different $(P<0.05)$.

${ }^{1}$ WPC samples from different manufacturing sites (as listed in Table 1).

tration of the internal standard to determine the relative abundance of the compound. The neutral/basic compounds were quantified from a DB-5MS column and acids were quantified using a DB-WAX column.

\section{Statistical Analyses}

Proximate analysis, sensory, and instrumental quantitation results were analyzed using the SAS statistical software (version 8.2, SAS Institute, Cary, NC). Proximate analysis and instrumental data were treated as a completely randomized design with repeated measures. Sensory data were treated as a randomized balanced block with repeated measures. Analysis of variance with means separation (least squares means) was conducted to identify differences among products.

\section{RESULTS AND DISCUSSION}

\section{WPC 80 and WPI Composition}

There were compositional differences among the different WPC 80 and WPI $(P<0.05$; Tables 3 and 4$)$. The
$\mathrm{pH}$ of these samples ranged from 5.8 to 6.9. There were no consistent differences between products made from Cheddar and Mozzarella whey. Although there were statistically significant differences in composition, products made from the same manufacturing site had similar proximate compositions and all products were within expected ranges for their proximate composition (Jelen, 2000). Due to the high degree of reproducibility within these measurements, statistical differences were observed among the WPC80 and the WPI, but these differences are likely not important from a practical standpoint as they pertain to the objectives of this study - the flavor of fresh dried whey proteins.

The main compositional differences identified were in the mineral content. This is expected because each facility has different ways of concentrating and processing the liquid whey. Different filtration and processing procedures may selectively filter out different minerals and salts. Additionally, WPC samples 1 through 5 were produced mainly from Mozzarella whey, whereas WPC samples 6 and 7 were produced from Cheddar whey; this could also contribute to some of the

Table 4. Proximate analysis of whey protein isolate (WPI) samples from different manufacturers.

\begin{tabular}{|c|c|c|c|c|c|c|c|}
\hline \multirow[b]{2}{*}{ Attribute } & \multirow{2}{*}{$\frac{\text { Manufacturer } 1}{\text { WPI } 2}$} & \multicolumn{2}{|c|}{ Manufacturer 5} & \multicolumn{2}{|c|}{ Manufacturer 4} & \multicolumn{2}{|c|}{ Manufacturer 6} \\
\hline & & WPI 3 & WPI 4 & WPI 5 & WPI 6 & WPI 7 & WPI 8 \\
\hline $\mathrm{pH}$ & $6.92^{\mathrm{a}}$ & $5.92^{\mathrm{c}}$ & $5.97^{\mathrm{c}}$ & $6.05^{\mathrm{bc}}$ & $6.14^{\mathrm{b}}$ & $6.22^{\mathrm{b}}$ & $5.91^{\mathrm{c}}$ \\
\hline Ash (\%, dry weight basis) & $2.02^{\mathrm{d}}$ & $2.40^{\mathrm{b}}$ & $2.17^{\mathrm{c}}$ & $1.96^{\mathrm{d}}$ & $2.19^{\mathrm{c}}$ & $2.43^{\mathrm{b}}$ & $2.54^{\mathrm{a}}$ \\
\hline Moisture (\%) & $4.15^{\mathrm{d}}$ & $6.04^{\mathrm{b}}$ & $6.03^{\mathrm{b}}$ & $6.65^{\mathrm{a}}$ & $5.32^{\mathrm{c}}$ & $3.37^{\mathrm{f}}$ & $3.68^{\mathrm{e}}$ \\
\hline Protein (\%, dry weight basis) & $93.94^{\mathrm{a}}$ & $88.22^{\mathrm{d}}$ & $87.90^{\text {ed }}$ & $87.69^{\mathrm{e}}$ & $85.85^{f}$ & $89.88^{\mathrm{b}}$ & $89.28^{\mathrm{c}}$ \\
\hline Fat (\%, dry weight basis) & $0.66^{\mathrm{b}}$ & $0.14^{\text {de }}$ & $0.25^{\mathrm{d}}$ & $0.19^{\text {de }}$ & $0.06^{\mathrm{e}}$ & $0.50^{\mathrm{c}}$ & $0.82^{\mathrm{a}}$ \\
\hline Calcium $(\mathrm{mg} / 100 \mathrm{~g})$ & $56.6^{\mathrm{e}}$ & $477.0^{\mathrm{c}}$ & $459.0^{\mathrm{d}}$ & $486.5^{\mathrm{c}}$ & $453.5^{\mathrm{d}}$ & $525.0^{\mathrm{b}}$ & $554.5^{\mathrm{a}}$ \\
\hline Magnesium (mg/100 g) & $2.5^{\mathrm{e}}$ & $74.8^{\mathrm{c}}$ & $80.5^{\mathrm{cd}}$ & $65.7^{\mathrm{d}}$ & $67.4^{\mathrm{d}}$ & $122.5^{\mathrm{b}}$ & $129.0^{\mathrm{a}}$ \\
\hline Potassium (mg/100 g) & $41.4^{\mathrm{e}}$ & $433.0^{\mathrm{b}}$ & $415.5^{\mathrm{c}}$ & $385.0^{\mathrm{d}}$ & $525.0^{\mathrm{a}}$ & $422.0^{\mathrm{c}}$ & $451.5^{\mathrm{b}}$ \\
\hline Sodium $(\mathrm{mg} / 100 \mathrm{~g})$ & $789.0^{\mathrm{a}}$ & $147.5^{\mathrm{c}}$ & $132.5^{\mathrm{cd}}$ & $108.5^{\mathrm{d}}$ & $159.5^{\mathrm{c}}$ & $231.5^{\mathrm{b}}$ & $219.0^{\mathrm{b}}$ \\
\hline Phosphate $(\mathrm{mg} / 100 \mathrm{~g})$ & $63.4^{\mathrm{f}}$ & $224.5^{\mathrm{b}}$ & $212.0^{c}$ & $154.5^{\mathrm{e}}$ & $197.0^{\mathrm{d}}$ & $219.0^{\mathrm{bc}}$ & $288.5^{\mathrm{a}}$ \\
\hline
\end{tabular}

${ }^{\mathrm{a}-\mathrm{f}}$ Means in a row followed by different letters are different $(P<0.05)$. 1.

${ }^{1}$ WPI samples from different manufacturing sites (as listed in Table 1); data were not available for WPI 
Table 5. Descriptive sensory analysis of whey protein concentrate (WPC 80) from different manufacturers. ${ }^{1,2}$

\begin{tabular}{|c|c|c|c|c|c|c|c|}
\hline \multirow[b]{2}{*}{ Attribute } & \multicolumn{2}{|c|}{ Manufacturer 1} & \multicolumn{2}{|c|}{ Manufacturer 2} & \multirow{2}{*}{$\frac{\text { Manufacturer } 3}{\text { WPC } 5}$} & \multicolumn{2}{|c|}{ Manufacturer 4} \\
\hline & WPC 1 & WPC 2 & WPC 3 & WPC 4 & & WPC 6 & WPC 7 \\
\hline Aroma intensity & $3.00^{\mathrm{a}}$ & $2.00^{\mathrm{b}}$ & $3.00^{\mathrm{a}}$ & $1.75^{\mathrm{b}}$ & $3.50^{\mathrm{a}}$ & $3.50^{\mathrm{a}}$ & $3.25^{\mathrm{a}}$ \\
\hline Sweet aromatic & ND & ND & $2.90^{\mathrm{a}}$ & $2.00^{\mathrm{b}}$ & $1.50^{\mathrm{c}}$ & ND & ND \\
\hline Cooked/milky & ND & ND & ND & ND & ND & $2.00^{\mathrm{a}}$ & $1.52^{\mathrm{a}}$ \\
\hline Cardboard/wet paper & $3.25^{\mathrm{a}}$ & $2.00^{\mathrm{b}}$ & ND & $1.50^{\mathrm{b}}$ & ND & ND & $3.25^{\mathrm{a}}$ \\
\hline Brothy & ND & ND & ND & ND & ND & $1.50^{\mathrm{a}}$ & ND \\
\hline Pasta water & ND & $1.50^{\mathrm{c}}$ & $1.50^{\mathrm{c}}$ & $2.50^{\mathrm{bc}}$ & $3.25^{\mathrm{ab}}$ & $4.00^{\mathrm{a}}$ & $2.50^{\mathrm{bc}}$ \\
\hline Doughy/fatty & ND & ND & $1.50^{\mathrm{a}}$ & ND & ND & ND & ND \\
\hline Astringency & $3.40^{\mathrm{a}}$ & $3.00^{\mathrm{ab}}$ & $2.75^{\mathrm{ab}}$ & $2.50^{\mathrm{b}}$ & $3.00^{\mathrm{ab}}$ & $2.50^{\mathrm{b}}$ & $2.25^{\mathrm{b}}$ \\
\hline
\end{tabular}

${ }^{\mathrm{a}, \mathrm{b}, \mathrm{c}}$ Means in a row followed by different letters are different $(P<0.05)$.

${ }^{1} \mathrm{WPC}$ samples from different manufacturing sites (as listed in Table 1).

${ }^{2}$ Intensities are scored on a 15 -point universal scale where $0=$ none and $15=$ very high (Meilgaard et al., 1999). ND = Not detected consistently by all panelists; mean intensity score $<0.50$.

observed variability in mineral composition. Previous studies have documented the remarkable variability in the composition of WPC 80 and WPI (Holt et al., 1999). These differences in composition, particularly ash, minerals, moisture, and fat, may play a crucial role in the flavor stability of these products with storage.

\section{Sensory Analysis}

Sensory profiles of rehydrated whey proteins are presented in Tables 5 and 6 . There were no consistent differences between products made from Cheddar and Mozzarella whey $(P<0.05)$. For both WPC 80 and WPI, significant differences $(P<0.05)$ in the sensory profiles were observed. Two general groups of aromatic flavors were found in the whey proteins-dairy and nondairy flavors. Drake et al. (2003) also documented these groups of flavors in skim and whole milk powder as well as dried whey ingredients and described the flavors as those flavors generally associated with fresh fluid milk or whey (dairy flavors: sweet aromatic, cooked/ milky) and those flavors not generally associated with fresh fluid milk or whey (nondairy flavors: cardboard, animal/wet dog, cucumber, etc.).

There were sensory differences among the WPC 80 made from different manufacturing sites. Samples 1, 2,4 , and $7 \mathrm{had}$ high intensities of cardboard/wet paper. Cardboard/wet paper has traditionally been a descriptor for oxidized milk fat (Morr and Ha, 1991), and this flavor has been documented in off-flavored skim and whole milk powder (Drake et al., 2003; Caudle et al., 2005). Samples 4 through 7 also had high intensities of pasta water flavor. Sweet aromatic and cooked/milky were 2 dairy flavors observed in the WPC80. All of the WPC 80 samples were astringent.

The WPI had similar flavor profiles to the WPC 80, but the attributes soapy, animal/wet dog, cucumber, and bitter (all nondairy flavors) were observed only in WPI (not in WPC 80). Delicate dairy flavors, sweet aromatic and cooked/milky, were not observed in the WPI. Isolate samples 1 and 2 had the highest intensities of soapy flavors, but displayed the lowest overall aroma intensities. Samples 3 through 8 were characterized by cardboard/wet paper flavor. Sample 6 was the only WPI

Table 6. Descriptive sensory analysis of whey protein isolate (WPI) samples from different manufacturers. ${ }^{1,2}$

\begin{tabular}{|c|c|c|c|c|c|c|c|c|}
\hline \multirow[b]{2}{*}{ Attribute } & \multicolumn{2}{|c|}{ Manufacturer 1} & \multicolumn{2}{|c|}{ Manufacturer 5} & \multicolumn{2}{|c|}{ Manufacturer 4} & \multicolumn{2}{|c|}{ Manufacturer 6} \\
\hline & WPI $1^{1}$ & WPI $2^{1}$ & WPI $3^{5}$ & WPI $4^{5}$ & WPI $5^{4}$ & WPI $6^{4}$ & WPI $7^{6}$ & WPI $8^{6}$ \\
\hline Aroma intensity & $1.75^{\mathrm{cd}}$ & $1.50^{\mathrm{d}}$ & $2.50^{\mathrm{bc}}$ & $3.40^{\mathrm{ab}}$ & $4.15^{\mathrm{a}}$ & $3.65^{\mathrm{a}}$ & $4.00^{\mathrm{a}}$ & $4.25^{\mathrm{a}}$ \\
\hline Cardboard/wet paper & ND & ND & $2.00^{\mathrm{ab}}$ & $2.25^{\mathrm{a}}$ & $1.50^{\mathrm{b}}$ & $2.25^{\mathrm{a}}$ & $2.00^{\mathrm{ab}}$ & $2.15^{\mathrm{ab}}$ \\
\hline Animal/wet dog & ND & ND & ND & $1.50^{\mathrm{b}}$ & $2.50^{\mathrm{a}}$ & ND & $1.50^{\mathrm{ab}}$ & $1.50^{\mathrm{ab}}$ \\
\hline Soapy & $3.00^{\mathrm{a}}$ & $2.50^{\mathrm{a}}$ & ND & $\mathrm{ND}$ & $\mathrm{ND}$ & $1.50^{\mathrm{b}}$ & $1.50^{\mathrm{b}}$ & ND \\
\hline Brothy & ND & ND & ND & ND & ND & ND & $2.00^{\mathrm{a}}$ & $1.00^{\mathrm{b}}$ \\
\hline Pasta water & ND & ND & ND & ND & ND & 2.00 & ND & ND \\
\hline Cucumber & ND & ND & ND & 1.50 & ND & ND & ND & ND \\
\hline Bitter taste & $1.25^{\mathrm{a}}$ & $1.00^{\mathrm{a}}$ & ND & ND & $0.58^{\mathrm{a}}$ & $0.50^{\mathrm{a}}$ & ND & ND \\
\hline Astringency & $2.00^{\mathrm{c}}$ & $1.50^{\mathrm{c}}$ & $3.00^{\mathrm{a}}$ & $2.75^{\mathrm{ab}}$ & $3.40^{\mathrm{a}}$ & $1.75^{\mathrm{bc}}$ & $2.50^{\mathrm{abc}}$ & $2.50^{\mathrm{abc}}$ \\
\hline
\end{tabular}

${ }^{\mathrm{a}-\mathrm{d}}$ Means in a row followed by different letters are different $(P<0.05)$.

${ }^{2}$ Intensities are scored on a 15 -point universal scale where $0=$ none and $15=$ very high (Meilgaard et al., 1999). ND = Not detected consistently by all panelists; mean intensity score $<0.50$. 
with pasta water flavor, and sample 4 was the only one with cucumber flavor. These flavors may be formed via lipid oxidation. There were small but significant differences in the fat content of the different WPI, however, there was no clear trend that higher fat content (within the range observed) was associated with increased lipid oxidation flavors such as cardboard/wet paper, cucumber, doughy/fatty, or pasta water. A lack of correlation between fat content and lipid oxidation flavors was also observed with WPC 80. As mentioned previously, it is possible that the observed differences in fat content among the WPI and WPC 80 samples might contribute to differences in flavor stability with increased storage time, even though they do not appear to impact flavor in the fresh product. Additional research would be necessary to confirm this hypothesis.

Though not observed in WPC 80, several of the WPI had animal/wet dog flavor. Animal/wet dog flavor is likely caused by protein degradation and has been previously identified as a characteristic flavor in caseins and caseinates (Karagul-Yuceer et al., 2003b; Drake et al., 2003). Whey protein isolates are high in protein, like caseins and caseinates, further associating this flavor with high protein products. Bitterness and astringency have been associated with proteolysis (Harwalker et al., 1993; Lee et al., 1996a; N'Kouka et al., 2004). The WPI samples $1,2,5$, and 6 had distinct bitter taste intensities. Bitterness was only observed in the WPI, not in the (lower protein) WPC 80, suggesting that as the protein content increases, so does the potential for bitterness. Consistently bland whey proteins should be the industry ideal. Recent research with low heat skim milk powder has demonstrated that low intensities of nondairy flavors (off-flavors) in milk powders carry through into ingredient applications, and negatively impact consumer acceptance (Caudle et al., 2005). Nondairy or off-flavor intensities in whey proteins are comparable to those observed in milk powders (Drake et al., 2003) and it is reasonable to assume that similar off-flavor carry-through potential exists with whey protein ingredient applications.

\section{GC/O and Odorant Quantification}

Post peak intensity aroma analysis of all samples was conducted (data not shown). The WPC 80 samples 1 and 2 were very similar, as were 3 and 4 , and 6 and 7. Whey protein isolate samples 1 and 2 were similar to each other, 3 and 4 were similar, and samples 5 through 8 were similar to each other. These results indicate, not surprisingly, that whey proteins from the same facilities have similar (but not necessarily identical) sensory and instrumental flavor profiles. From these preliminary results and descriptive sensory data,
4 representative WPC 80 (samples 2, 3, 5, and 6) and 3 representative WPI (samples 2, 4, and 7) were selected to further pinpoint aroma-active compounds by using the semiquantitative sniffing technique, AEDA. Fortyone potent $\left(\log _{3} \mathrm{FD}<1\right)$ aroma-active compounds in WPC and 28 potent $\left(\log _{3}\right.$ FD $\left.<1\right)$ aroma-active compounds in WPI were detected (Tables 7 and 8). In both WPC 80 and WPI there were aldehydes, ketones, and free fatty acids. The aldehydes hexanal, octanal, nonanal, and decanal have been previously identified in both liquid and dried whey ingredients (Lee et al., 1996b; Stevenson and Chen, 1996; Carunchia Whetstine et al., 2003a; Karagul-Yuceer et al., 2003a). These compounds are formed during lipid oxidation as the oxidation of lipids produces a wide range of compounds including aldehydes, ketones, and alcohols (Frankel et al., 1981). Low molecular weight aldehydes have low aroma thresholds (Kinsella et al., 1967; Rychlik et al., 1998) and therefore contribute to flavor. Because there is less fat in WPI than in WPC 80 (approximately $0.5 \%$ vs. 5\%, respectively), there were fewer aroma-active lipid oxidation products identified in WPI compared with WPC 80.

1-Octen-3-one, dienals, and (Z)-4-heptenal have all been implicated as sources of off-flavors in dairy products that have undergone oxidation (Morr and Ha, 1991). Unsaturated aldehydes have been previously identified in sweet whey powder (Mahajan et al., 2004) and are formed from the autooxidation of unsaturated fatty acids. Hexanal (Karagul-Yuceer et al., 2002), 1octen-3-one (Day et al., 1963), (Z)- and (E)-2-nonenal (Grosch et al., 1994), (E,Z)-2,6-nonadienal, and (E,E)2,4-decadienal (Karagul-Yuceer et al., 2001, 2002) likely contribute to cardboard or metallic flavors in liquid whey and dried whey products (Karagul-Yuceer et al., 2003a; Drake et al., 2003). There were no large or consistent differences in the $\log _{3}$ flavor dilution values for hexanal (grassy), Z-4-heptanal (fatty/fishy), or octanal (citrus/green) among the WPC 80 samples. However, WPC 80 sample 1 contained more fat than WPC 80 samples 3,5 , and 6 (Table 3); higher flavor dilution values for decanal (fatty) and the unsaturated aldehyde (E,E)-2,4-decadienal (oxidized) were also documented in this sample (Table 7). The relative concentration of the short-chain aldehydes was higher in the WPC 80 than in the WPI (Tables 9 and 10), consistent with the higher fat content of the WPC 80. These short-chain aldehydes have low aroma thresholds. However, low molecular weight compounds may be entrapped by the protein in WPC 80 and WPI (Stevenson and Chen, 1996), which would increase their threshold values. Therefore, the threshold values for these compounds in spray-dried WPC 80 and WPI may be much higher than previously reported threshold values in water or buffer. 
Table 7. Aroma extract dilution analysis of whey protein concentrate (WPC) samples.

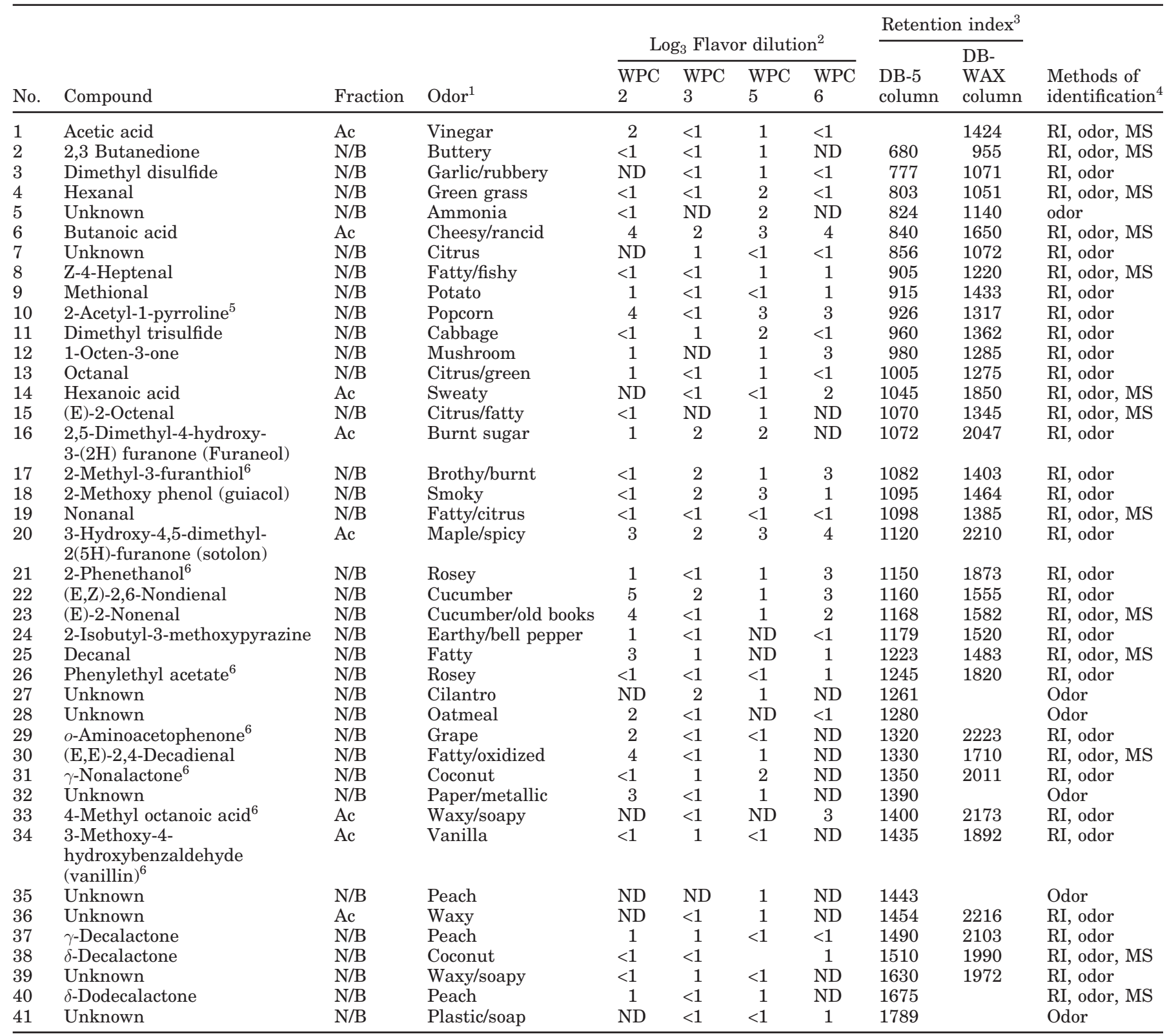

${ }^{1}$ Odor description at the gas chromatograph (GC) sniffing port.

${ }^{2}$ Flavor dilution factors were determined on a DB-5MS column for neutral/basic (N/B) compounds, and on a DB-WAX column for acidic (Ac) compounds.

${ }^{3}$ Retention indices were calculated from gas chromatography/olfactory data.

${ }^{4}$ Compounds were identified by comparison with the authentic standards on the following criteria: retention index (RI) on DB-WAX and DB-5MS columns, odor property at the GC sniffing port, and mass spectra in the electron impact mode. Positive identifications indicate that mass spectral data was compared with authentic standards.

${ }^{5}$ Compound identified by comparing RI and aroma with literature (Avsar et al., 2004).

${ }^{6}$ Compound not previously identified as an aroma-active constituent of whey (Mills, 1993; Stevenson and Chen, 1996; Carunchia Whetstine et al., 2003a; Karagul-Yuceer et al., 2003a; Mahajan et al., 2004).

This hypothesis would explain why there does not appear to be a direct correlation between the concentration of aldehydes and the sensory perception of offflavor intensity in fresh products (Tables 4, 5, 9, and 10).
Carunchia Whetstine and Drake (2005) also observed inconsistent correlations between total aldehyde concentrations and off-flavors in skim milk powder less than 6 mo old. 
Table 8. Aroma extract dilution analysis of representative whey protein isolate (WPI) samples.

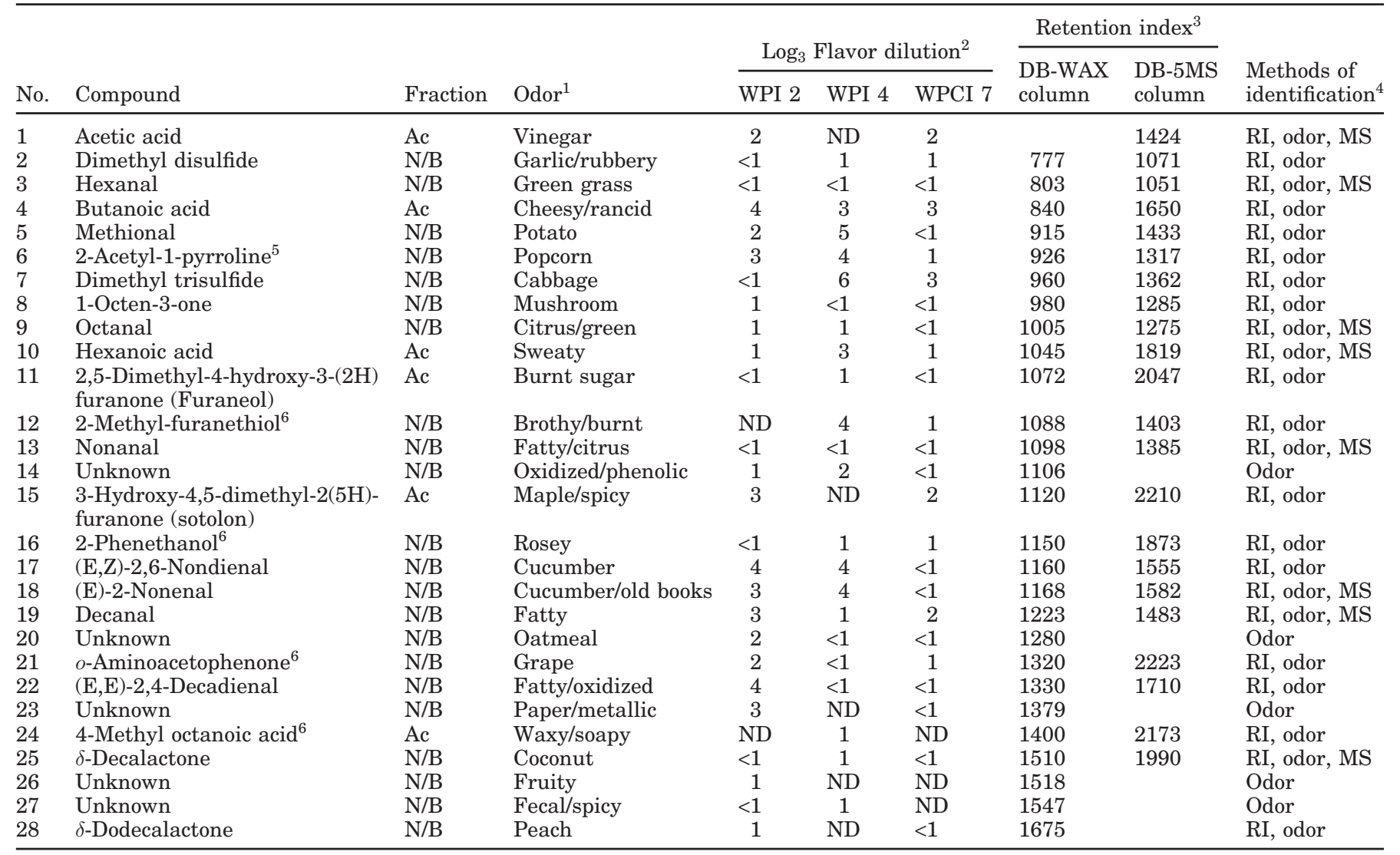

${ }^{1}$ Odor description at the gas chromatograph (GC) sniffing port.

${ }^{2}$ Flavor dilution factors were determined on a DB-5MS column for neutral/basic (N/B) compounds, and on a DB-WAX column for acidic (Ac) compounds.

${ }^{3}$ Retention indices were calculated from gas chromatography/olfactory data.

${ }^{4}$ Compounds were identified by comparison with the authentic standards on the following criteria: retention index (RI) on DB-WAX and DB-5MS columns, odor property at the GC-sniffing port, and mass spectra in the electron impact mode. Positive identifications indicate that mass spectral data was compared with authentic standards.

${ }^{5}$ Compound identified by comparing RI and aroma with literature (Avsar et al., 2004).

${ }^{6}$ Compound not previously identified as an aroma-active constituent of whey (Mills, 1993; Stevenson and Chen, 1996; Carunchia Whetstine et al., 2003a; Karagul-Yuceer et al., 2003a; Mahajan et al., 2004).

There were several fatty acids identified in both WPC 80 and WPI. Previous studies have identified many different short-chain fatty acids in whey, ranging in chain length from C2 to C18 (Lee et al., 1996b; Tomaino et al., 2001; Karagul-Yuceer et al., 2003a). Acetic acid, butanoic acid, hexanoic acid, and 4-methyl octanoic acid were the only acids identified by GC/O (i.e., displaying aroma activity). Butanoic and hexanoic were found in similar concentration ranges ( 1 to $10 \mathrm{ppm}$ ) as those previously reported in liquid whey (Karagul-Yuceer et al., 2003a). The free fatty acids C4-C8 have lower sensory threshold values than the fatty acids larger than C10 (Tables 9 and 10), which is why they play a larger role in flavor (Karagul-Yuceer et al., 2003a). Octanoic, nonanoic, and decanoic acids were detected by gas chromatography/mass spectrometry only (Tables 9 and 10).
The branched-chain fatty acid 4-methyl octanoic acid has not been previously identified in whey. This compound is not found in high concentrations in cows' milk, but is found in high concentrations in goat and sheep milk (3, 223, and $80 \mathrm{ppm}$, respectively; Ha and Lindsay, 1991). Carunchia Whetstine et al. (2003b) found that this acid, in conjunction with 4-ethyl octanoic acid, was the source of waxy/animal flavor in goat cheese. The odor threshold of this compound is around $20 \mathrm{ppb}$ at $\mathrm{pH} 2.0$ and the retronasal threshold is $600 \mathrm{ppb}$ in water (Brennand et al., 1989). In all WPC 80 and most of the WPI samples, 4-methyl octanoic acid was present below sensory threshold. In WPI sample 1, 4-methyl octanoic acid was above threshold and might have contributed to the soapy/waxy flavor in this product. However, this acid was present in other samples that did not have 
Table 9. Relative abundance of selected compounds in whey protein concentrate (WPC) samples (ND = not detected).

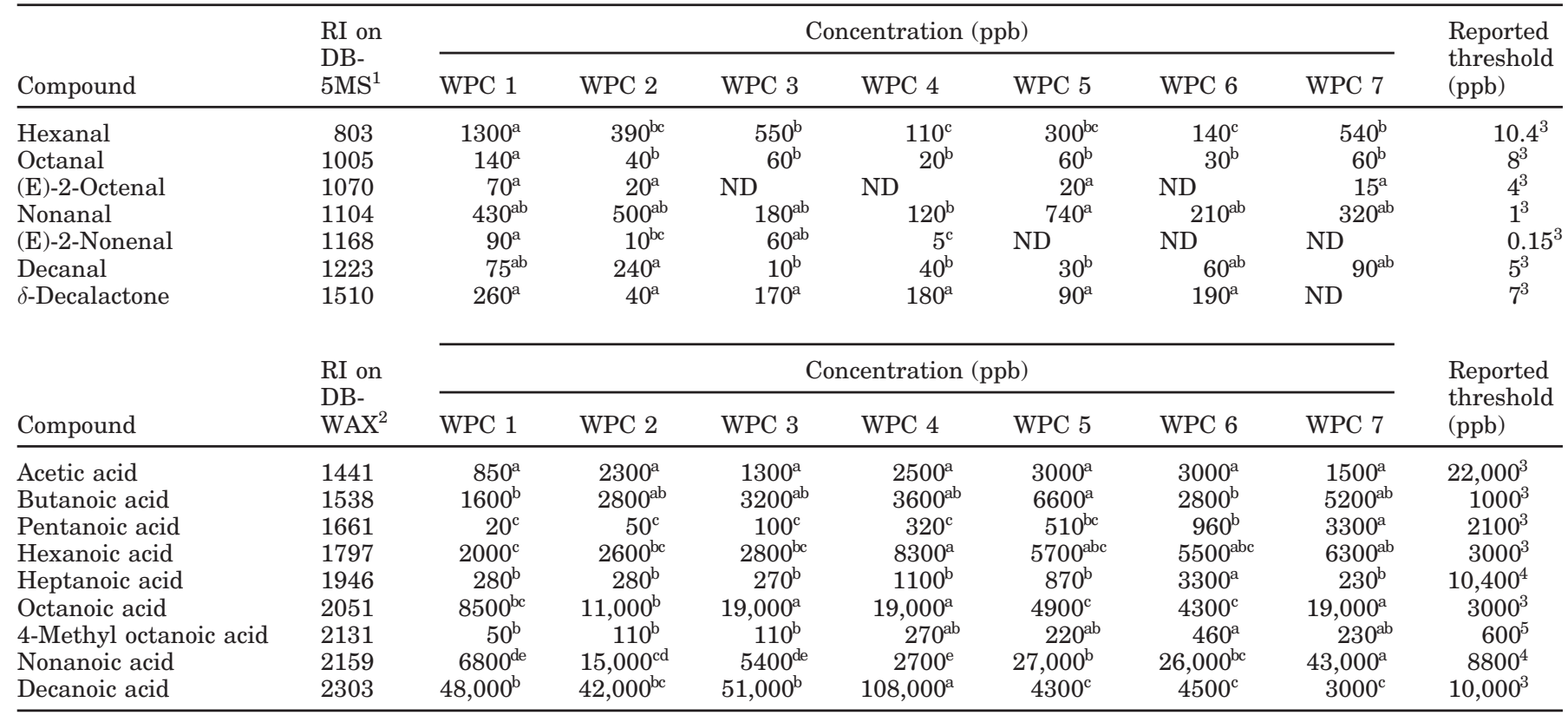

${ }^{\mathrm{a}-\mathrm{e}}$ Means in a row followed by different letters are different $(P<0.05)$.

${ }^{1}$ Retention indices (RI) calculated from mass spectrometry results on a DB-5 column.

${ }^{2} \mathrm{RI}$ calculated from flame-ionization detector results on a DB-Wax column.

${ }^{3}$ Thresholds reported orthonasally in water (Rychlik et al., 1998).

${ }^{4}$ Thresholds reported in a potassium-hydrogen-phthalate buffer at $\mathrm{pH} 4.8$ (Attaie and Richter, 1996).

${ }^{5}$ Thresholds reported in water at $\mathrm{pH} 4$ to 5 (Brennard et al., 1989).

the characteristic soapy flavor, and so other compounds likely contribute to this flavor. Octanoic and decanoic acids were identified in WPI. These acids have been previously identified in whey (Tomaino et al., 2001). Octanoic and decanoic acids also have waxy/soapy aromas and were found at significantly higher concentrations $(P<0.05)$ in WPI samples 1 and 2 , both of which had the soapy flavor. These data suggest that increased concentrations of octanoic and decanoic acids in WPI also contribute to waxy/soapy flavors.

There were many thermally generated compounds such as pyrrolines, pyrazines, and furanones. Again, this is expected because WPC 80 and WPI undergo spray drying in which residual lactose can react with protein to form Maillard reaction products or undergo caramelization reactions (Friedman, 1996; Mahajan et al., 2004). 2-Acetyl-1-pyrroline (tentative ID) had high $\log _{3}$ FD values in most samples. This compound has a very low odor threshold and contributes to cooked flavors in fresh fluid whey and fresh low-heat skim milk powders (Karagul-Yuceer et al., 2001, 2002, 2003a, 2004). 3-Hydroxy-4,5-dimethyl-2(5H)-furanone (sotolon) also had high $\log _{3}$ FD values in all WPC 80 . This compound was previously identified as a key aroma component of sweet whey powder (Mahajan et al., 2004). 2,5-Dimethyl-4-hydroxy-3-(2H)-furanone (fu- raneol) was found in some WPC 80 and WPI. This compound has also been previously identified in sweet whey powder (Mahajan et al., 2004) and is a sugar degradation product with a sweet, candy-like aroma. In general, these thermally generated compounds contribute to typical dairy flavors, such as cooked/milky and sweet aromatic. It is important to note their presence in WPC 80 and WPI, but our interest lies in understanding offflavor formation, and these compounds are likely not sources of off-flavors in fresh dried whey products.

There were 4 sulfur compounds identified in the whey proteins. Methional, dimethyl sulfide, and dimethyl trisulfide have been previously identified in liquid and dried whey (Karagul-Yuceer et al., 2003a; Mahajan et al., 2004). Methional was one of the first compounds identified in dairy products and is a Strecker degradation product formed from the degradation of methionine. Dimethyl disulfide and dimethyl trisulfide have onion and cabbage odors, respectively. These compounds are formed from the degradation of methionine into dimethyl sulfide and methanethiol and then into dimethyl disulfide and dimethyl trisulfide (Bendall, 2001). Although the sulfur compound 2-methyl furanthiol (brothy/burnt) has not been previously found in whey, it has been previously identified in Cheddar cheese (Carunchia Whetstine et al., 2005) and is formed 
Table 10. Relative abundance of selected compounds in whey protein isolate (WPI) samples $(\mathrm{ND}=$ not detected $)$.

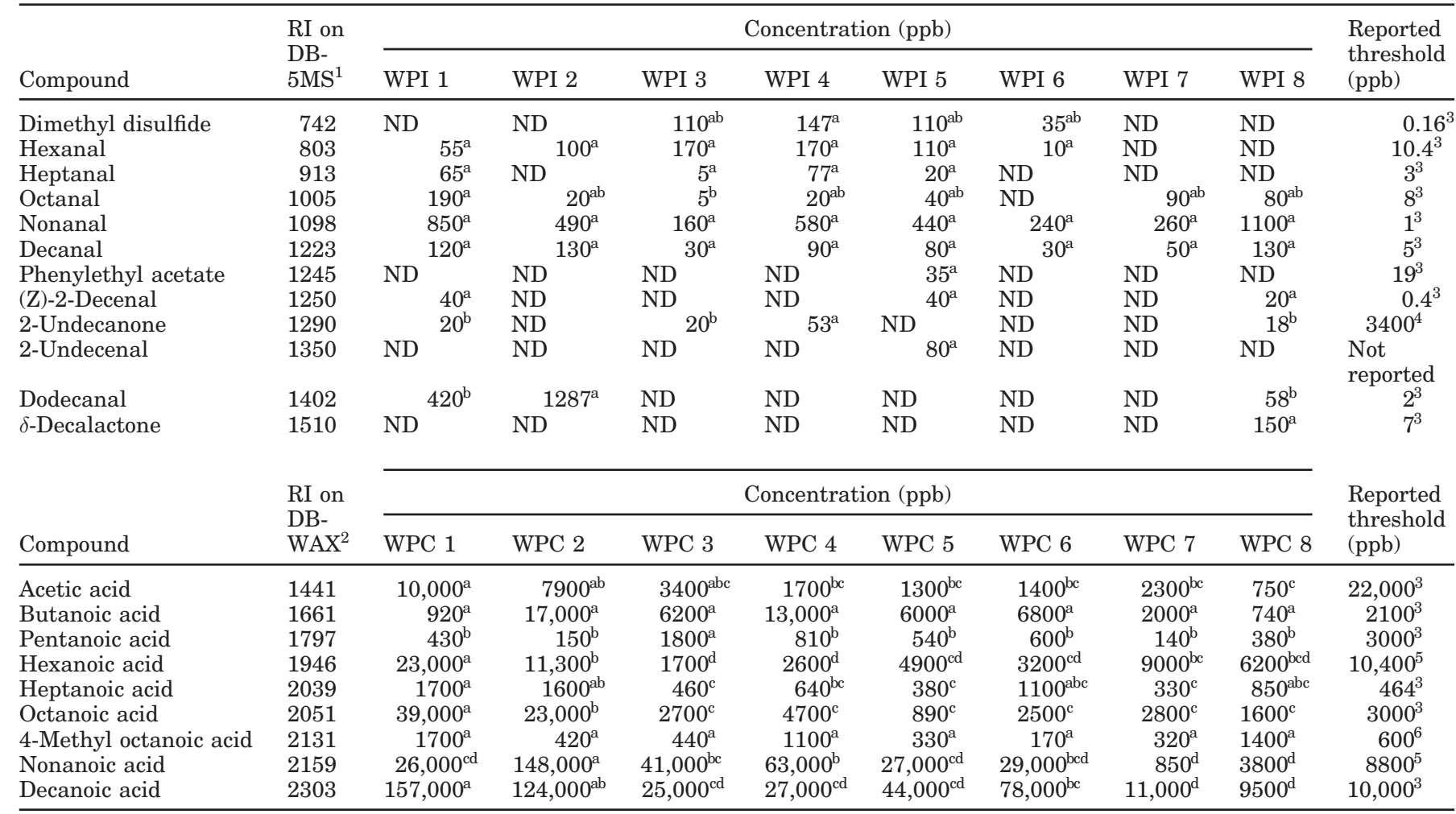

${ }^{\mathrm{a}-\mathrm{d}}$ Means in a row followed by different letters are different $(P<0.05)$.

${ }^{1}$ Retention indices (RI) calculated from mass spectrometry results on a DB-5 column.

${ }^{2} \mathrm{RI}$ calculated from flame-ionization detector results on a DB-Wax column.

${ }^{3}$ Thresholds reported orthonasally in water (Rychlik et al., 1998).

${ }^{4}$ Threshold reported orthonasally in oil (Rychlik et al., 1998).

${ }^{5}$ Thresholds reported in a potassium-hydrogen-phthalate buffer at pH 4.8 (Attaie and Richter, 1996).

${ }^{6}$ Thresholds reported in water at $\mathrm{pH} 4$ to 5 (Brennard et al., 1989).

from the degradation of sulfur-containing amino acids (Lee et al., 1996b). These sulfur compounds are sources of brothy flavors in Cheddar cheese (Singh et al., 2003) and probably contribute to these flavors in WPC 80 and WPI.

2-Phenethanol and phenyl ethyl acetate have not been previously identified in whey, but are found in aged Cheddar cheese and are formed from the Strecker degradation of aromatic amino acids, especially phenylalanine (Singh et al., 2003; Carunchia Whetstine et al., 2005). Another degradation product of phenylalanine, phenylacetaldehyde, has been previously documented in sweet whey powder (Mahajan et al., 2004). 2-Methoxyphenol (guaiacol) has a smoky aroma and was found in all WPC 80. This compound is found in aged cheese (Suriyaphan et al., 2001; Singh et al., 2003) and can be formed from the degradation of aromatic amino acids. 2-Isobutyl-3-methoxypyrazine, which has an earthy aroma, was identified in some WPC 80 samples. This compound was previously identified in liquid whey
(Karagul-Yuceer et al., 2003a), and is responsible for the characteristic earthy aroma in British farmhouse Cheddar cheese (Suriyaphan et al., 2001). The degradation of amino acids can cause distinctive flavors in aged products, such as Cheddar cheese (Carunchia Whetstine et al., 2005), but the liberation of free amino acids is a slow process (Wallace and Fox, 1997). This is most likely why this mechanism of flavor formation is not as prevalent as lipid oxidation reactions in nonaged products such as whey, and why lipid oxidation products are the main sources of flavor (Tables 7 and 8; Swaisgood, 1996).

$o$-Aminoacetophenone has not been previously identified in WPC 80 or WPI, but was found in these samples. This compound has been documented in other dried dairy ingredients including skim milk powder and rennet casein (Karagul-Yuceer et al., 2002, 2003b). oAminoacetophenone has been reported to cause stale flavor in milk powders and is present at higher concentrations in stored skim milk powder compared with 
fresh skim milk powder (Karagul-Yuceer et al., 2002). This compound is not likely a key flavor compound in fresh WPC 80 and WPI, but may be important in stored products. 2,3-Butanedione (diacetyl) has a buttery aroma and has been documented in many fermented dairy products including liquid whey and sweet whey powder (Karagul-Yuceer et al., 2003a; Mahajan et al., 2004). It was found in WPC 80 at low levels. This compound is produced during lactic fermentation by the oxidative decarboxylation of $\alpha$-acetolactic acid (Cronin and Rispin, 1996).

There are several compounds in WPC 80 and WPI that are formed from triglycerides during the pasteurization of milk (Badings and Neeter, 1980; El Soda et al., 1995). These include $\delta$-lactones and $\gamma$-lactones. Fresh raw milk does not contain lactones, but after pasteurization, lactones are formed (Dimick et al., 1969). $\gamma$-Nonalactone has not been previously found in whey but has been identified in skim powders (KaragulYuceer et al., 2002). Lactones generally display coconut or peach aromas (Singh et al., 2003). Based on aroma, there are several unknown compounds in the whey proteins that are likely lactones (Tables 6 and 7). The mechanism of lactone formation is nonoxidative and the precursors of these compounds are $\delta$-hydroxy fatty acids esterified in milk fat (Dimick et al., 1969). Due to the lower amount of lipid found in WPI, there are fewer lactone compounds in these samples compared with WPC 80. 3-Methoxy-4-hydroxybenzaldehyde (vanillin) was also identified in WPC 80, but not in WPI. Vanillin originates (in the cow rumen) from plant lignin. This compound is formed during pasteurization (Cobb et al., 1963). Vanillin has not been previously identified in WPC 80 or WPI, but has been identified in skim milk powder (Karagul-Yuceer et al., 2001, 2002).

Tables 9 and 10 show the relative concentration of selected compounds. These compounds were selected for quantification based on their aroma potency as well as mass selective detection limits. Though other compounds may indeed be important to the flavor of WPC 80 and WPI, they were not present at high enough concentrations to be quantified instrumentally. There were no consistent differences in the relative abundances of the neutral/basic compounds between the samples, but WPI samples 1 and 2 had higher concentrations of fatty acids C8-C10.

There were more aroma-active compounds in WPC 80 than in WPI. However, there were not correspondingly more flavors or higher flavor intensities observed in the WPC 80 compared with the WPI. Morr and Ha (1991) reported that commercial WPI exhibited considerable "better" flavor quality than WPC 80. Their statement was based on qualitative observations and because WPC 80 contain more residual lactose, lipid, phospho- lipid, lipoprotein, copper, and other prooxidants that increase the likelihood of lipid oxidation occurring (Morr and Ha, 1991) compared with WPI. Indeed, WPC 80 contained higher mineral (ash) content (dry weight basis) than WPI, which may correspond to production or detection of more aroma-active compounds. Additionally, proteins can bind or trap volatile compounds (Quach et al., 1999) and protein, and thus volatile binding capacity is higher in WPI, which might explain the presence of more aroma-active compounds in WPC 80 than in WPI. However, in contrast to previous studies, close examination of the sensory profiles does not reveal a clear "better" flavor quality between WPC 80 and WPI. Dried dairy proteins, including WPC 80 and WPI, should ideally exhibit delicate bland flavors reminiscent of fresh fluid whey or milk. Cardboard/wet paper, pasta water, soapy, and cucumber flavors as well as bitter taste and astringency are not desirable sensory attributes in dairy products. Further work should address the formation of these undesirable nondairy flavors during processing as well as addressing flavor carry-through of these ingredients into product applications.

\section{CONCLUSIONS}

Before this study, there was no quantitative research examining the flavor of multiple WPC 80 and WPI from different manufacturers. This study sheds light on the compounds that contribute to WPC 80 and WPI flavor. Flavor variability (sensory and instrumental) was observed between and within WPC 80 and WPI. Mild dairy flavors (cooked/milky, sweet aromatic) as well as nondairy flavors (cardboard, pasta water, animal/wet dog) were documented in the rehydrated proteins. Lipid oxidation products in conjunction with heat-generated compounds were predominant sources of flavors. This research demonstrates the range and variability of aroma-active compounds and flavors in WPC 80 and WPI. Further research needs to be conducted to more fully aid the industry in providing consistent, bland WPC 80 and WPI ingredients.

\section{ACKNOWLEDGMENTS}

Funding provided by the California Dairy Research Foundation and Dairy Management, Inc. Manuscript 05-24 of the Department of Food Science, North Carolina State University (Raleigh). The use of trade names in the publication does not imply endorsement by these organizations nor criticisms of ones not mentioned.

\section{REFERENCES}

Amundson, C. H. 1984. Residual milk clotting enzymes. Pages 2-10 in Proc. 1984 Whey Products Conf., Chicago, IL. 
Attaie, R., and R. L. Richter. 1996. Formation of volatile free fatty acids during ripening of Cheddar-like hard goat cheese. J. Dairy Sci. 79:717-724.

Avsar, Y., Y. Karagul-Yuceer, M. A. Drake, T. Singh, Y. Yoon, and K. R. Cadwallader. 2004. Characterization of nutty flavor in Cheddar cheese. J. Dairy Sci. 87:1999-2010.

Badings, H. T., and R. Neeter. 1980. Recent advances in the study of aroma compounds of milk and dairy products. Neth. Milk Dairy J. 34:9-30.

Bendall, J. G. 2001. Aroma compounds of fresh milk from New Zealand cows fed different diets. J. Agric. Food Chem. 49:4825-4832.

Branger, E. B., C. A. Sims, R. H. Schmidt, S. F. O'Keefe, and J. A. Cornell. 1999. Sensory characteristics of cottage cheese whey and grapefruit juice blends and changes during processing. J. Food Sci. 64:180-184.

Brennand, C. P., J. K. Ha, and R. C. Lindsay. 1989. Aroma properties and thresholds of some branched-chain and other minor volatile fatty acids occurring in milkfat and meat lipids. J. Sens. Stud. $4: 105-120$.

Carunchia Whetstine, M. E., J. Parker, M. A. Drake, and D. K. Larick. 2003a. Determining flavor and flavor variability in commercially produced liquid Cheddar whey. J. Dairy Sci. 86:439-448.

Carunchia Whetstine, M. E., Y. Karagul-Yuceer, Y. K. Avsar, and M. A. Drake. 2003b. Identification and quantification of character aroma components in fresh Chevre-style goat cheese. J. Food Sci. 68:2441-2447.

Carunchia Whetstine, M. E., K. R. Cadwallader, and M. A. Drake. 2005. Characterization of aroma compounds responsible for rosy/ floral flavor in Cheddar cheese. J. Agric. Food Chem. 53:31263132.

Carunchia Whetstine, M. E., and M. A. Drake. 2005. The flavor and flavor stability of skim and whole milk powders. Chapter 6 in Flavor of Dairy Products. ACS Symposium Series, Washington, DC.

Caudle, A. D., Y. Yoon, and M. A. Drake. 2005. Influence of flavor variability in skim milk powder on consumer acceptability of ingredient applications. J. Food Sci. 70:5427-5431.

Cobb, W. Y., S. Patton, and H. Grill. 1963. Occurrence of vanillin in heated milks. J. Dairy Sci. 46:566-567.

Cronin, D. A., and E. Rispin. 1996. The determination of diacetyl in cultured buttermilk in the presence of the unstable precursor $\alpha$ acetolactic acid. Pages 118-121 in Flavour science recent developments. A. J. Taylor and D. S. Mottram, ed. The Royal Society of Chemistry. Cambridge, UK.

Day, E., D. A. Lillard, and M. W. Montgomery. 1963. Autoxidation of milk lipids. III. Effect on flavor of the additive interactions of carbonyl compounds of subthreshold concentrations. J. Dairy Sci. 46:291-294.

Dimick, P. S., N. J. Walker, and S. Patton. 1969. Occurrence and biochemical origin of aliphatic lactones in milk fat - A review. J. Agric. Food Chem. 17:649-655.

Drake, M. A., and G. V. Civille. 2003. Flavor lexicons. Comp. Rev. Food Sci. Food Safety 1:33-39.

Drake, M. A., Y. Karagul-Yuceer, K. R. Cadwallader, G. V. Civille, and P. S. Tong. 2003. Determination of the sensory attributes of dried milk powders and dairy ingredients. J. Sens. Stud. 18:199-208.

El Soda, M., J. Law, E. Tsakalidou, and G. Kalantzopoulos. 1995. Lipolytic activity of cheese related microorganisms and its impact on cheese flavor. Pages 1823-1847 in Food Flavors, Generation Analysis and Process Influence. G. Charalambous, ed. Elsevier Science, New York, NY.

Frankel, E. N., W. E. Neff, and E. Selke. 1981. Analysis of autooxidized fats by gas chromatography-mass spectrometry: VIII Volatile thermal decomposition products of pure hydroperoxides from autooxidized and photosensitized methyl oleate, linaleate, and linolenate. Lipids 16:279-285.

Friedman, M. 1996. Food browning and its prevention. J. Agric. Food Chem. 44:631-653.

Grosch, W. 1993. Detection of potent odorants in foods by aroma extract dilution analysis. Trends Food Sci. Technol. 4:68-73.
Grosch, W., C. Milo, and S. Widder. 1994. Identification and quantification of odorants causing off-flavors. Pages 509-515 in Trends in Flavour Research. H. Maarse and D. G. Van der Heij, ed. Elsevier, London, UK.

Ha, J. K., and R. C. Lindsay. 1991. Contributions of cow, sheep, and goat milks to characterizing branched-chain fatty acid and phenolic flavors in varietal cheeses. J. Dairy Sci. 74:3267-3274.

Harwalker, V. R., H. Cholette, R. C. McKellar, and D. B. Emmons. 1993. Relation between proteolysis and astringent off-flavor in milk. J. Dairy Sci. 76:2521-2527.

Hidalgo, F. J., and J. E. Kinsella. 1989. Changes induced in $\beta$-lactoglobulin B following interactions with linoleic acid 13-hydroperoxide. J. Agric. Food Chem. 37:860-866.

Holmes, D. G., J. W. Duersch, and C. A. Ernstrom. 1977. Distribution of milk clotting enzymes between curd and whey and their survival during Cheddar cheese making. J. Dairy Sci. 60:862-869.

Holt, C., D. McPhail, I. Nevison, T. Nylander, J. Otte, R. H. Ipsen, L. Ogendal, R. Bauer, K. Olieman, K. G. de Kruif, C. Leonil, D. Molle, G. Henry, J. L. Maubois, M. D. Perez, S. Puyol, M. Calva, S. M. Bury, G. Kontopidis, I. McNai, L. Sawyer, L. Ragona, L. Zetta, H. Molinari, B. Klarenbeek, H. J. Jonkman, J. Moulin, and D. Chatterton. 1999. Apparent chemical composition of nine commercial or semi-commercial whey protein concentrates, isolates and fractions. Int. J. Food Sci. Technol. 43:543-556.

Jelen, D. 2000. Whey: Composition, properties, processing, and uses. Pages 2652-2661 in Wiley Encyclopedia of Food Science and Technology. 2nd ed. F. J. Francis, ed. Wiley, New York, NY.

Karagul-Yuceer, Y., K. R. Cadwallader, and M. A. Drake. 2002. Volatile flavor components of stored nonfat dry milk. J. Agric. Food Chem. 50:305-312.

Karagul-Yuceer, Y., M. A. Drake, and K. R. Cadwallader. 2001. Aroma-active components of nonfat dried milk. J. Agric. Food Chem. 49:2948-2953.

Karagul-Yuceer, Y., M. A. Drake, and K. R. Cadwallader. 2003a. Aroma-active components of liquid Cheddar whey. J. Food Sci. 68:1215-1219.

Karagul-Yuceer, Y., K. N. Vlahovich, M. A. Drake, and K. R. Cadwallader. 2003b. Characteristic aroma compounds of rennet casein. J. Agric. Food Chem. 51:6797-6801.

Karagul-Yuceer, Y., M. A. Drake, and K. R. Cadwallader. 2004. Evaluation of the character impact odorants in skim milk powder by sensory studies on model mixtures. J. Sens. Stud. 19:1-14.

Kinsella, J. E., S. Patton, and P. S. Dimick. 1967. The flavor potential of milk fat. A review of its chemical nature and biological origin. J. Am. Oil Chem. Soc. 44:449-454.

Lee, K. D., C. G. Lo, and J. J. Warthesen. 1996a. Removal of bitterness from the bitter peptides extracted from Cheddar cheese with peptidases from Lactococcus lactis ssp. cremoris SK11. J. Dairy Sci. 79:1521-1528.

Lee, Y. B., I. Laye, Y. D. Kim, and C. V. Morr. 1996b. Formation of volatile compounds in whey protein concentrate during elevated temperature storage as a function of water activity. Int. Dairy J. 6:485-496.

Mahajan, S. S., L. Goddick, and M. C. Qian. 2004. Aroma compounds in sweet whey powder. J. Dairy Sci. 87:4057-4063.

Mavropoulou, I. P., and F. V. Kosikowski. 1972. Free amino acids and soluble peptides of whey powders. J. Dairy Sci. 56:1135-1138.

McGugan, W. A., E. Larmond, and D. B. Emmons. 1979. Some observations on the flavor of acid whey. J. Institut Canadien de Sci. Tech. Alimentarie. 12:3-35.

Meilgaard, M. M., G. V. Civille, and B. T. Carr. 1999. Selection and training of panel members. Pages 174-176 in Sensory Evaluation Techniques, 3nd ed. CRC Press, Boca Raton, FL.

Mills, O. E. 1993. Flavour of whey protein concentrate. New Zealand Dairy Research Institute. Pages 139-149 in Food Flavors, ingredients, and composition. Proc. 7th Int. Flavor Conf. Elsevier, New York, NY

Milo, C., and G. Reineccius. 1997. Identification and quantification of potent odorants in regular-fat and low-fat mild Cheddar cheese. J. Agric. Food Chem. 45:3590-3594. 
Morr, C. V., and E. A. Foegeding. 1990. Composition and functionality of commercial whey and milk protein concentrates and isolates: A status report. Food Technol. April:100-112.

Morr, C. V., and E. Y. W. Ha. 1991. Off-flavors of whey protein concentrates: A literature review. Int. Dairy J. 1:1-11.

N'Kouka, K. D., B. P. Klein, and S. Y. Lee. 2004. Developing a lexicon for descriptive analysis of soymilks. J. Food Sci. 69:259-263.

Quach, M. L., X. D. Chen, and R. J. Stevenson. 1999. Headspace sampling of whey protein concentrate solutions using solid-phase microextraction. Food Res. Int. 31:371-379.

Rychlik, M., P. Schieberle, and W. Grosch. 1998. Compilation of thresholds, odor qualities, and retention indices of key food odorants. Deutsche Forschungsanstalt fur Lebensmittelchemie and Instiut fur Lebensmittelchemie der Technischen Universitat Munchen. Garching, Germany.

Singh, T., M. A. Drake, and K. R. Cadwallader. 2003. Flavor of Cheddar cheese: A chemical and sensory perspective. Comp. Rev. Food Sci. Food Safety 2:139-162.

Stevenson, R. J., and X. D. Chen. 1996. A study of volatile "trapping" in spray-dried whey protein concentrate by "crushing" and/or vacuuming, and detection by solid-phase microextraction/gas chromatography/mass spectrometry. Food Res. Int. 29:495-504.
Suriyaphan, O., M. A. Drake, X. Q. Chen, and K. R. Cadwallader. 2001. Characteristic aroma components of British farmhouse Cheddar cheese. J. Agric. Food Chem. 49:1382-1387.

Swaisgood, H. E. 1996. Characteristics of milk. Pages $841-876$ in Food Chemistry. 3rd ed. O. R. Fennema, ed. Marcel Dekker, New York, NY

Tomaino, R. T., J. D. Parker, and D. K. Larick. 2001. Analysis of free fatty acids in whey products by solid-phase microextraction. J. Agric. Food Chem. 49:3993-3998.

USDA. 2005. U.S. Total whey powder production. United States Department of Agriculture. Online. Available: http://www.ams.usda.gov/dairy/mncs/graphs/whey\%5Fprod.pdf. Accessed Feb. 19, 2005.

Van den Dool, H., and P. Kratz. 1963. A generalization of the retention index system including linear programmed gas liquid partition chromatography. J. Chromatogr. 11:463-471.

Van Ruth, S. 2001. Methods for gas chromatography-olfactometry: A review. Biomol. Eng. 17:121-128.

Wallace, J., and P. Fox. 1997. Effect of adding free amino acids to Cheddar cheese curd on proteolysis, flavour and texture development. Int. Dairy J. 7:157-167.

Wehr, H. M., and J. F. Frank. 2004. Standard Methods for the Examination of Dairy Products. Pages 380-382; 427-434; 440-441; 447449; 480-495. American Public Health Association. Washington, DC. 